University of Nebraska - Lincoln

DigitalCommons@University of Nebraska - Lincoln

Faculty Publications in the Biological Sciences

Papers in the Biological Sciences

7-1915

American Species of the Genus Atractides

Ruth Marshall

University of Nebraska - Lincoln

Follow this and additional works at: https://digitalcommons.unl.edu/bioscifacpub

Part of the Life Sciences Commons

Marshall, Ruth, "American Species of the Genus Atractides" (1915). Faculty Publications in the Biological Sciences. 23.

https://digitalcommons.unl.edu/bioscifacpub/23

This Article is brought to you for free and open access by the Papers in the Biological Sciences at DigitalCommons@University of Nebraska - Lincoln. It has been accepted for inclusion in Faculty Publications in the Biological Sciences by an authorized administrator of DigitalCommons@University of Nebraska - Lincoln. 


\title{
AMERICAN SPECIES OF THE GENUS ATRACTIDES
}

\author{
By Ruth Marshall
}

The water mites of the genus Atractides belong to a small subfamily, the Hygrobatina. About ten species have been described by European hydrachnologists for Europe; two of these species have been reported by them also from North America, while one species is described for Madagascar. Three new species are now added to the list for the United States. All of the material, thirtyeight individuals, was found by the author in small lakes in Wisconsin.

The species comprising this group are easily recognized; but, unfortunately, there has been much confusion in the use of the name Atractides. By some authors it has been used as a synonym for the genus Megapus of Neuman, and given as the valid name for the genus Torrenticola of Piersig. The nomenclature used by Piersig (1901) and by Wolcott (1905) seems to the author to be logical, and it is used in this paper.

The body of these mites is oval or elliptical; the integument is usually soft, with a surface covering finely striated or porous. The epimera are in three groups, with the capitulum lying in close contact with the first pair. The most distinctive feature is the oblique placing of the third pair and the more or less truncate margin of the fourth. The genital area is placed about midway between the epimera and the end of the body; the cleft in both sexes is flanked on either side by three conspicuous acetabula on a sickle-shaped plate, another distinctive feature of the genus. In the female the cleft is long and the acetabula are removed from it; in the male the shorter cleft is completely enclosed by the plates bearing the acetabula.

The palpi are about as thick as the legs. The joints of the palpi increase in length from the first to the fourth, while the fifth is small and claw-like. A distinctive feature of the genus is the 
presence of two hairs on papillæ on the ventral side of the fourth joint, and a sword-like spine on the inner side. This fourth joint usually bears some fine hairs.

The legs do not vary greatly in length; all of them bear spines and a few hairs. The first leg is most distinctive; it is often longer and stouter than the second, and the last joint shows more or less bending. These features are pronounced in figures published by European writers on the genus; they are not conspicuous features of the three new American species here described.

Atractides parriscutus nov. spec.

P1. VI, Fig. 1-4

This is a large mite, the largest specimen measuring $1.3 \mathrm{~mm}$. The epimeral plates occupy an uncommonly small part of the ventral surface. The spaces between the groups of plates are large. The surface of the body, including the plates, is very finely porous. On both dorsal and ventral surfaces the plates marking the openings of the skin glands are prominent; in balsam mounts the glands are strongly outlined, and fine hairs may be made out on the plates.

The legs are much alike; the first two pairs have about the same length. The first pair are only a trifle the stouter, while the last joint shows but little bending. The palpi are slender.

Only the female of the species was found in a collection of twenty-six individuals, all from Wisconsin lakes. Four of these were found in Nagowicka and Neshota lakes, near Milwaukee, in the fall of 1908; eighteen in Lake Spooner, in northwestern Wisconsin, in the summer and fall of 1909; two in Lake Minocqua, in the northern part of the state, in July, 1912 ; and two in the Lauderdale Lakes, in southern Wisconsin, August 12, 1914.

Atractides phenopleces nov. spec.

P1. VI, Fig. 5-9

This species is founded upon the examination of a single specimen, a female from Lake Spooner, Wisconsin (Aug. 18, 1909). It measured $1.1 \mathrm{~mm}$. in length. The epimeral plates show fewer of the irregularities of surface than do those of some species, and the 
posterior borders of the fourth plates are sharply truncate. Certain small characters which distinguish this from related species are best brought out by the figures. The lateral plates of the genital area bearing the acetabula are large and somewhat removed from the rest of the area. The first pair of legs show the bending of the last joint so characteristic of the genus.

Atracides orthopes nov. spec.

Pl. VI, Fig. 10-12

This new species is represented here by six males, three from Lake Nagowicka, near Milwaukee (Oct. 15, 1908), and three from Lake Spooner, Wisconsin (July 16, 1909). It resembles $A$. gibberipalpus Piersig in the character of the epimeral plates, which show irregular surfaces and a close proximity of the three groups. The palpi are fairly stout, and the last joint of the first leg is very long and shows no trace of bending; in these particulars the new species differs from the related one. The two sword-like bristles on the distal end of the fifth joint of the first leg are very large. The surface of the body appears very finely granular, the plates more so. The length of the body is $0.65 \mathrm{~mm}$.

\section{BIBLIOGRAPHY}

KoENIKe, F.

1898. Hydrachniden-fauna von Madagascar und Nossi-Bé.

Abh. Senck. naturf. Gesell., XXI, ii :416, pl. XXVI, fig. 128-130.

1895. Nordamerikanische Hydrachniden. Abh. naturw. Vereins

Bremen, XIII :211-212, pl. III, fig. 58-59.

1909. Die Süsswasser Fauna Deutschlands, XII : 89-94. Jena. MAGLIo, C.

1905. Secondo Elenco d'Idracne del Pavese.

Rendiconti del R. 1st Lomb. di. sc. e lett., XXXVIII, 2:152-154.

Neuman, C.

1880. Om Sveriges Hydrachnider. Kongl. Svenska Vet.-Akad. Hndlgr., XVII :63-65, pl. I, fig. 4.

Piersig., R.

1897. Deutschlands Hydrachniden. Bibliotheca Zoologica, XXII :186-190, pl. XV̀III, fig. 45. Stuttgart, 1897-1900. 
1898. Hydrachnidenforman aus der Hohen Tatra. Zool. Anz., XXI:12. Neue Hydrachnidenformen aus dem sachsischen Erzgebirge. Zool. Anz., XXI :523-524.

1901. Hydrachnidæ (und Halacaridæ). Das Tierreich, XIII :181-185.

1904. Ueber eine neue Hydrachnide aus dem Böhmer Walde. Zool. Anz., XXVII :453-454.

Thor, Sig.

1899. Tredie Bidrag til Kundskaben om Norges Hydrachnider. Arch. Math. Naturv., XXI, 5 :38-40, pl. XVII, fig. 119-121.

WolcotT, R. H.

1905. A Review of the Genera of the Water Mites. Trans. Amer. Mic. Soc., XXVI:219. (Repr. as Studies from the Zool. Lab., Univ. of Nebraska, No. 66).

\section{EXPLANATION OF FIGURES}

Fig. 1. Atractides parviscutus nov. spec., ventral view.

Fig. 2. Atractides parviscutus nov. spec., dorsal view.

Fig. 3. Atractides parviscutus nov. spec., right palpus, inner side.

Fig. 4. Atractides parviscutus nov. spec., legs, left side.

Fig. 5. Atractides phenopleces nov. spec., ventral view.

Fig. 6. Atractides phenopleces nov. spec., 1st leg, left side.

Fig. 7. Atractides phenopleces nov. spec., 4th leg, left side.

Fig. 8. Atractides phenopleces nov. spec., genital field, female.

Fig. 9. Atractides phenopleces nov. spec., left palpus and capitulum.

Fig. 10. Atractides orthopes nov. spec., ventral view.

Fig. 11. Atractides orthopes nov. spec., 5th, 6th joints, right 1 st leg.

Fig. 12. Atractides orthopes nov. spec., right palpus, outer side. 


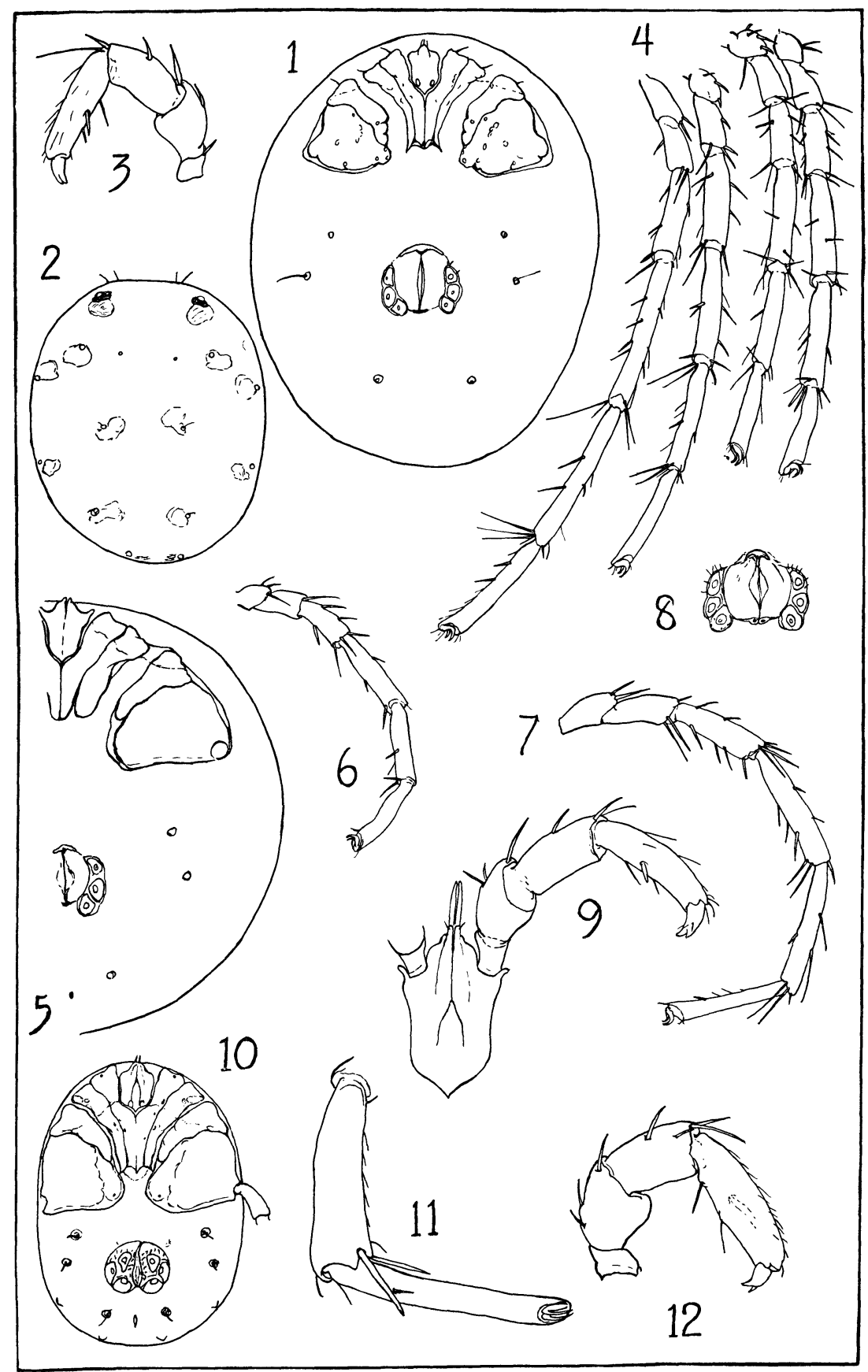

Plate VI 